\title{
The use of the Delphi Method adjusted to evaluate the Stork Network: from Image-objective to Reality
}

O uso do Método Delphi ajustado para avaliar a Rede Cegonha: da Imagem-objetivo à Realidade Uso del Método Delphi ajustado para evaluar la Rede Cegonha: de la Imagen-objetivo a la Realidad

\author{
Antônio Augusto Vieira de $\operatorname{Aragão}^{1}($ \\ Sydia Rosana de Araújo Oliveira ${ }^{1}$ (1) \\ Garibaldi Dantas Gurgel Júnior ${ }^{1}$ (C)
}

1. Fundação Oswaldo Cruz, Instituto Aggeu

Magalhães. Recife, PE, Brasil.
Corresponding Author:

Antônio Augusto Vieira de Aragão.

E-mail: augustoapevisa@gmail.com.

Submitted on $11 / 01 / 2018$

Accepted on 01/22/2019.

DOI: 10.1590/2177-9465-EAN-2018-0318

\section{Abstract}

This study aims to evaluate the Stork Network (SN), a new pattern of intergovernmental program. The method was applied through the adjusted Delphi Method, with 13 specialists. It was constituted in 3 moments. A Logical Model (LM) was elaborated, with the purpose of showing the design of the actions of the program and its main components. By consensus the Delphi Matrix of Concordance with the proposal of the Goal Image was elaborated and validated. Finally, this Matrix was used as an instrument to evaluate the degree of implementation of the program. The results show that SN is classified in the Unsatisfactory Level, in the III Macro-regional Health in Pernambuco, corroborating the irrelevance of initiatives developed to strengthen the program. It is concluded that the application of this Delphi Method was consistent with the complexity of the object, given the lack of specific models for this purpose based on new institutional relations in the regionalization of the Unified Health System (SUS, acronym in Portuguese). This study showed its implications for nursing practice in the search for solutions for patient safety in materna and child health care, pointing out the indispensability of these professionals to make SN more effective, especially in the face of a vulnerable and disadvantaged population in the interior of the semi-arid region, in an adverse political-economic scenario.

Keywords: Public Health; Maternal and Child Health; Health Evaluation; Health Policy.

\section{REsUMO}

Este estudo objetiva avaliar a Rede Cegonha (RC), um novo padrão de programa intergovernamental. O Método foi aplicado por meio do Método Delphi ajustado, com 13 especialistas. Constituiu-se em três momentos. Foi elaborado um Modelo Lógico (ML), com o propósito de mostrar o desenho das ações do programa e seus principais componentes. Por consenso, foi elaborada e validada a Matriz Delphi de Concordância com a proposta da Imagem-objetivo. Finalmente, essa Matriz foi utilizada como instrumento de avaliação do Grau de Implantação do programa. Os Resultados mostram que a RC está classificada em Níve Insatisfatório, na III Macrorregional de Saúde em Pernambuco, corroborando a irrelevância das iniciativas desenvolvidas para fortalecer o programa. Conclui-se que a aplicação desse Método Delphi se mostrou coerente com a complexidade do objeto, diante da carência de modelos específicos para essa finalidade, baseada em novas relações institucionais na regionalização do Sistema Único de Saúde (SUS). Este estudo mostrou suas implicações com a prática de enfermagem, na busca de soluções para segurança das pacientes na atenção à saúde maternoinfantil, apontando a imprescindibilidade desses profissionais para tornar a RC mais efetiva, sobretudo diante de uma população vulnerabilizada e desfavorecida, no interior do semiárido, num cenário político-econômico adverso.

Palavras-chave: Saúde Pública; Saúde Maternoinfantil; Avaliação em Saúde; Política de Saúde.

\section{Resumen}

Este Estudio objetiva evaluar la Rede Cegonha (RC), un nuevo estándar de programa intergubernamental. El Método fue aplicado a través del Método Delphi ajustado, con 13 especialistas. Constituyó en 3 momentos. Elaboró un Modelo Lógico (ML), con el propósito de mostrar el diseño de las acciones del programa y sus principales componentes. Por consenso es elaborada y validada la Matriz Delphi de Concordancia con la propuesta de la Imagen-objetivo. Esta Matriz se utiliza como instrumento de evaluación del Grado de Implantación del programa. Los resultados muestran la RC clasificada en Nivel Insatisfactorio en la III Macrorregional de Salud en Pernambuco, corroborando la irrelevancia de las iniciativas desarrolladas para fortalecer el programa. Se concluye que la aplicación de este Método Delphi, se mostró coherente con la complejidad del objeto, ante la carencia de modelos específicos para esa finalidad basada en la regionalización del Sistema Único de Salud (SUS). Este estudio mostró sus implicaciones con la práctica de enfermería, pues buscó proporcionar soluciones, en el área de la Atención a la Salud Materno-infantil, apuntando la imprescindibilidad del enfermero como base para hacer la RC más efectiva, sobre todo ante una población vulnerada y desfavorecida, interior del semiárido, en un escenario político-económico adverso.

Palabras clave: Salud Pública; Salud Materno-infantil; Evaluación en Salud; Política de Salud. 


\section{INTRODUCTION}

In Brazil, since 2000, several themes of concern in the Public Health agenda have merited relevance, including the Maternal and Child Health Care ${ }^{1}$. In this context, in 2011, an intergovernmental policy initiative to address the health problems of this follow-up was the implementation of the Network of Storks Network (SN) throughout the country ${ }^{2}$, with an innovative standard based on non-verticalized actions for network execution of public services.

In the Unified Health System (SUS), this program was articulated in view of the need to increase public expenditures for assistance to the maternal and child segment, given the worrisome health situation related to the precarious indicators of morbidity and mortality reaching this target population, specifically associated to prenatal, childbirth and puerperium ${ }^{1,2}$.

With this program, there was an improvement in the scenario with the increase of resources destined to qualify the attention of the mother-child binomial. However, this situation once again showed great vulnerability related to this population group ${ }^{3,4}$, especially with the institutional crisis and the new cycle of contractionary policies in the SUS ${ }^{4,5}$.

Although the maternal mortality rate (MM) in the country in 2015 was $56 \%$ lower than in 1990, in a sign of stabilization, from 2017 onwards, that rate raised again ${ }^{6-8}$. The Northeast Region presents higher rates of maternal and infant morbidity and mortality in relation to the other regions of the country, leading to the prioritization of investment in this region, in order to accelerate the reduction of these inequalities ${ }^{2}$.

A troubling issue is that the $\mathrm{SN}$ program was implemented in the country in a context that had a relative convergence of political purposes as a national priority among SUS managers, which allowed the target audience to focus on the agreed actions in an economically favorable scenario ${ }^{9-12}$.

However, the current conjuncture of changes in direction in the country's health policy resulted in a reduction in the articulation capacity of the program in the political agenda of SUS managers, leading to a reduction in spending, reverberating in the situation of SN with negative impact on mother and child follow-up ${ }^{3,4,6}$.

Factors identified from the implementation of the actions and the confrontation should be subject to rigorous evaluation, due to the nature of this intergovernmental initiative directed to the sharing of sanitary responsibilities, in a regional network of public health services ${ }^{6,9}$. A challenging factor should be highlighted in relation to the traditional models of evaluation of vertical public health programs, when performed isolatedly in the decentralization process by the municipalities ${ }^{10,11}$.

The network implementation of regional health services presupposes the need to improve the capacity of regional governance to solve problems related to the fragmentation of actions and disarticulation of the organization of services. These factors have made it difficult to improve indicators ${ }^{6,9,12}$, with an impact on the poorest regions of the country.

The initiative to develop intergovernmental actions for
Maternal and Child Health, based on programs with this characteristic, requires the elaboration of new methodologies and evaluation techniques that prioritize to accurately and rigorously address issues related to the interdependence of services, to the continuous articulation of health care and the sharing of responsibilities in the governance process ${ }^{13}$, of the responsible network, for decision-making in the planning and execution of actions in the SN program ${ }^{14,15}$.

The new assignments delegated to Managing Committees and the regional mobilization around the program, based on the agreed priorities for the implementation of actions, monitoring and evaluation of strategies ${ }^{13}$, with new mechanisms and guiding instruments for the assembly of integrated regional networks is part of this new complex scenario for the development of public health programs in the SUS, based on Federal Decree No. $7.508 / 11$.

The institutionalization of Regional Interagency Commissions (CIRs, acronym in Portuguese) aimed at creating an uninterrupted channel of negotiation and decision-making between municipalities and the state health authority, in the context that points to a "vacuum" of governance ${ }^{13}$, is challenging for science. This situation lacks innovative evaluation methods to understand the implementation process of Health Care Networks (RAS, acronym in Portuguese). Among these Priority Thematic Networks in SUS, the Maternal and Child Health Care Network, where the SN Program is inserted, stands out.

Therefore, it is opportune to judge the complexity of this initiative, because its results should be able to compel changes in public policies, related to SN, defined by the Ministry of Health (MS), whose responsibility is shared in SUS ${ }^{10,17,18}$.

This work aims to evaluate the $\mathrm{SN}$, this new intergovernmental program standard implanted in a health macro-region in the Northeast of Brazil, through the application of the adjusted Delphi Method, which seems propitious to us due to the scarcity of specific models that approach this object.

\section{METHOD}

The method of this study is based on the construction of the Logic Model (LM) ${ }^{19,22}$ as a tool for the systematic and visual representation of the program, which rationally shows the sequence of steps and relationships that lead to the expected effects $^{19,20}$, where the program theory is made explicit ${ }^{21}$. LM is supported by investigative triangulation, with the association of qualitative research instruments ${ }^{23,24}$.

This research applies the Delphi Method ${ }^{25,27}$; which uses the selection and participation of "specialist" individuals in an interactive way, based on "feedback" and rounds of answers, by defined criteria. In a $1^{\text {st }}$ Delphi moment, an LM was elaborated for the SN with the selected specialists, whose purpose is to show the design of the actions of the program and its main components, in order to verify whether it is structured to reach the desired result ${ }^{22}$. In the $2^{\text {nd }}$ Delphi moment, based on the $M L$, by means of a consensus, the Delphi Matrix of Concordance with the Proposal of the SN goal Image was elaborated and 
validated, and in the $3^{\text {rd }}$ Delphi moment, this Matrix was used as an evaluation tool ${ }^{24,28}$ of the Degree of Deployment (GI, acronym in Portuguese) of the program, among the specialists, in the macro-regional scope in SUS.

This method responds to the need for the network evaluation of regional services, based on expert opinion, consistent with the complexity of the unstructured object; because it intends to evaluate the implantation process and institutional relations in the SUS at the regional level.

This work was carried out between April 2017 and August 2018. The research scenario was the area of the III Macro Regional Health, in the state of Pernambuco; located in northeastern semi-arid region; which encompasses the jurisdictions of three Regional Offices (VI, X and XI Geres); composed of 35 municipalities; with an estimated population of 830 thousand inhabitants ${ }^{29}$.

The documentary research was based on official publications of the Ministry of Health: through the MS Ordinances No. 1.459/11, No. 650/11, No. 2.351/11, No. 3.161/11, No. 3.242/11, No. $77 / 12$, No. 1.226/12, No. 1.020/13; Official Journal of the Union (DOU, acronym in Portuguese); State Department of Health (SES-PE, acronym in Portuguese); Pernambucano Management Committee of the Stork Network (CGPRC, acronym in Portuguese); Permanent Technical Chamber (CTP, acronym in Portuguese) of the Regional Health Departments of the State; National Council of Health Secretaries (CONASS, acronym in Portuguese); and, Council of Municipal Health Secretaries (COSEMS, acronym in Portuguese).

LM aimed at guiding the initial Delphi moment of the evaluation to address the regionalization of this program, which is a political-institutional process that contemplates the planning, organization of networks and implementation of intergovernmental health actions in the macro-region. This traditional instrument is valid for the development of normative evaluation of health programs $^{28}$. To support the elaboration of LM, the greatest problem was Infant Mortality (IM) and Maternal Mortality (MM), due to the high number of undesirable pregnancies, difficulty in accessing pregnant women to quality prenatal care, and their pilgrimage at the time of delivery. In it, the final objectives, and the proximal and distal results of this process were specified according to revised documents for the execution of the action (Figure 1).

In the $2^{\text {nd }}$ moment Delphi, based on the LM, the Delphi Matrix was elaborated in accordance with the Target Image Proposal, for the evaluation of the Stork Network, by specialists at the Macro Regional Level (Chart 1), based on the theoretical references and the main relevant aspects. This matrix was built from the components of the SN, which leads to the final objectives, where they lead to the expected final results of the program.

This Matrix was composed by dimensions ${ }^{30}$, oriented by the

Figure 1. Logic Model of the Stork Network (SN) - Rede Cegonha (RC)

Source: Logical Model elaborated and established by MS Ordinance No 1.459/11.

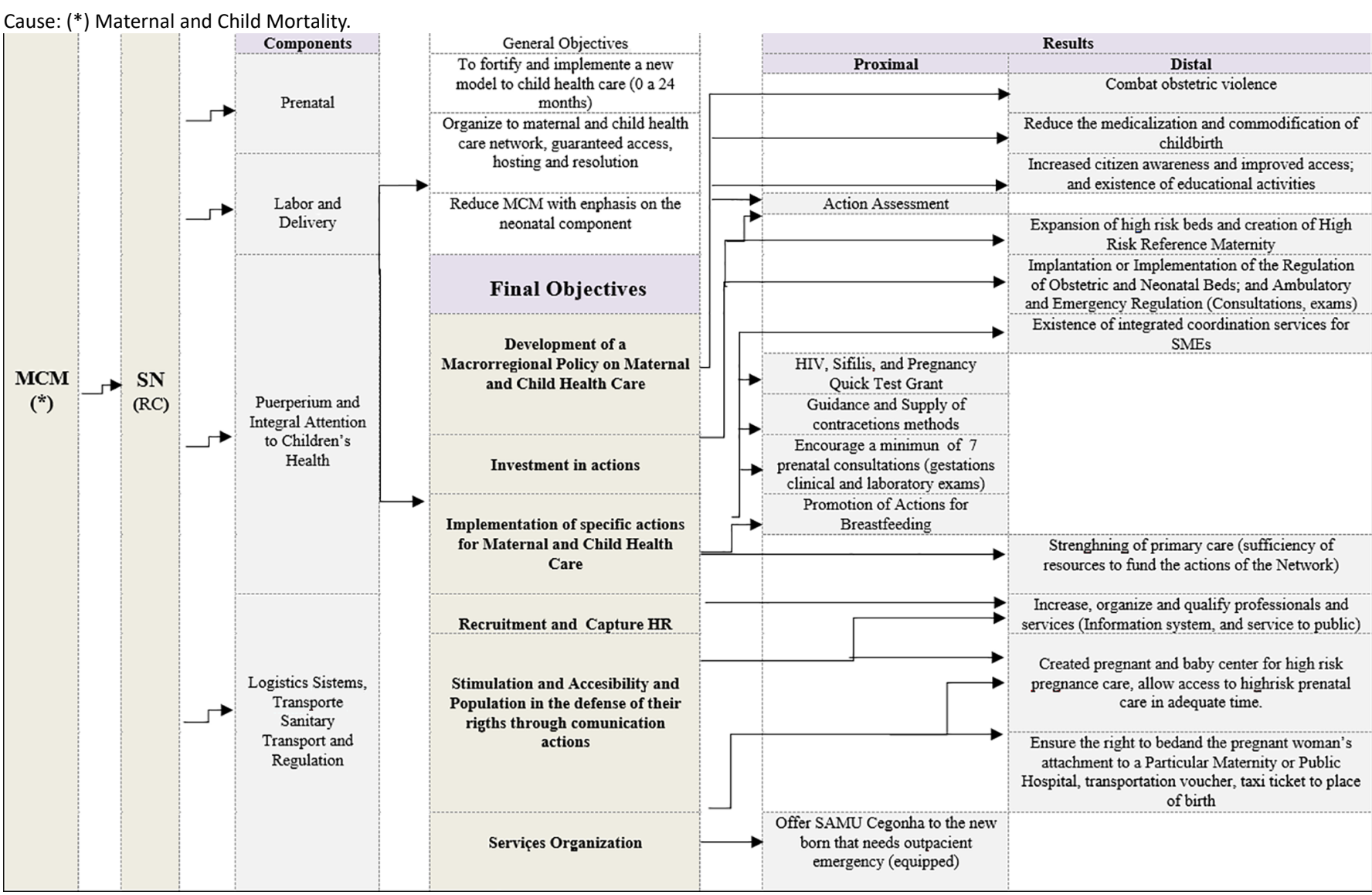


Chart 1. Delphi Matrix of Concordance with Objective Image Proposal for the evaluation of the Stork Network at the Macro Regional Level.

\begin{tabular}{|c|c|c|}
\hline \multicolumn{3}{|c|}{ Proposal of Image-objective for the evaluation of the Stork Network at Macro regional Level } \\
\hline \multicolumn{2}{|r|}{ Managenment Level } & \multirow{2}{*}{$\frac{\text { Level fo Agreement }}{\text { Proposed Score }}$} \\
\hline Dimension (Final Objectives) & Fundamentals & \\
\hline \multirow{7}{*}{$\begin{array}{l}\text { (a) Macro regional Policy and } \\
\text { Legislation }\end{array}$} & $\begin{array}{l}\text { 1. Exist a legal instrument to enhance the conduct of the negotia- } \\
\text { tions in CIR, to effect the SN. }\end{array}$ & 0 to 10 \\
\hline & $\begin{array}{l}\text { 2. Exist politic allusive to the citizen conscience the educational } \\
\text { activities }\end{array}$ & 0 to 10 \\
\hline & 3. Exist na action plan for the Stork Network & 0 to 10 \\
\hline & $\begin{array}{l}\text { 4. Carry out negotiations that took place in the CIR to conduct } \\
\text { the SN. }\end{array}$ & 0 to 10 \\
\hline & $\begin{array}{l}\text { 5. Use of strategic information regarding the planningand structu- } \\
\text { ring process of } \mathrm{SN} \text {, for the CIR pacts. }\end{array}$ & 0 to 10 \\
\hline & $\begin{array}{l}\text { 6. Have interdepartamental agreement among municipalities in } \\
\text { order to achieve objectives proposaed to strengthen integrality in } \\
\text { contexct of SN. }\end{array}$ & 0 to 10 \\
\hline & $\begin{array}{l}\text { 7. There are new stepts to strengthen the capacity to imple- } \\
\text { mentSN in the current context of the regional governance sys- } \\
\text { tem. }\end{array}$ & 0 to 10 \\
\hline \multirow{4}{*}{ (b) Investment in Stocks } & $\begin{array}{l}\text { 1. Have high-risk bed extension and high-risk reference maternal } \\
\text { setting. }\end{array}$ & 0 to 10 \\
\hline & $\begin{array}{l}\text { 2. Have implantation or implementation of regulation of obstetric } \\
\text { and neonatal beds, ambulatory, emergency regulations, consulta- } \\
\text { tions, exams. }\end{array}$ & 0 to 10 \\
\hline & 3. Have an evaluation of SN's actions. & 0 to 10 \\
\hline & $\begin{array}{l}\text { 4. Have loregional alternatives for the improvement of invest- } \\
\text { ments aiming at the continuity of SN's actions. }\end{array}$ & 0 to 10 \\
\hline \multirow{3}{*}{$\begin{array}{l}\text { (c) Implementation of specific } \\
\text { actions in Maternal and Child } \\
\text { Health Care }\end{array}$} & 1. Exist integrated maternal and child health cordination services. & 0 to 10 \\
\hline & $\begin{array}{l}\text { 2. Have SN's compliance with what is proposed by administrative } \\
\text { Rule No } 1.459 / 11 \text { (MS). }\end{array}$ & 0 to 10 \\
\hline & $\begin{array}{l}\text { 3. Exist a strengthening of primary care (sufficiency of resources } \\
\text { to fund SN's actions). }\end{array}$ & 0 to 10 \\
\hline \multirow{2}{*}{$\begin{array}{l}\text { (d) Contracting and capturing } \\
\text { Human Resources }\end{array}$} & $\begin{array}{l}\text { 1. Exist increase, organization and professional and servisse quali- } \\
\text { fication (information system and customer service) }\end{array}$ & 0 to 10 \\
\hline & $\begin{array}{l}\text { 2. Exist tecnichal staff that meets needs (doctors, nurses, among } \\
\text { others.) }\end{array}$ & 0 to 10 \\
\hline \multirow{2}{*}{$\begin{array}{l}\text { (e) Stimulation of the popula- } \\
\text { tion in defense of the righs to } \\
\text { comunication }\end{array}$} & $\begin{array}{l}\text { 1. Have the criation of pregnancy and baby centers, pregnancy } \\
\text { care centers, and access high-risk prenatal care in a timely man- } \\
\text { ner. }\end{array}$ & 0 to 10 \\
\hline & $\begin{array}{l}\text { 2. Exist communication between colleges and population about } \\
\text { the condution of the Stork Network }\end{array}$ & 0 to 10 \\
\hline \multirow[t]{2}{*}{ (f) Services Organization } & $\begin{array}{l}\text { 1. Exist a guarantee for the right to the bedand the attachment } \\
\text { of the pregnant woman to a particular maternity or public } \\
\text { hospital,transportation voucher, taxi-ticket, to the place of birth. }\end{array}$ & 0 to 10 \\
\hline & $\begin{array}{l}\text { 2. Have the SAMU Stork servisse offeredto the newborn who } \\
\text { needs outpatients emergency (Equipped). }\end{array}$ & 0 to 10 \\
\hline
\end{tabular}

Source: Authors. 
final objectives, and proximal and distal fundamentals ${ }^{31}$, to make a judgment of the components of the SN strategy, by means of consensus measurement through the use of the Delphi Method ${ }^{25-27}$.

An adaptation called the Adjusted Delphi Method was selected, as it was based on the inclusion of at least one round of in-person discussion ${ }^{32-35}$, through the combination with the application of the Consensus Conference Technique ${ }^{36}$, in a third Delphi moment, to evaluate the Degree of Implantation (GI, acronym in Portuguese) of SN in the Macro-Regional Health III.

The methodological criteria indicate that the number of members for the realization of the Delphi Consensus is relative; seven experts are recommended at a minimum, taking into account that the consensus error decreases considerably for each specialist added $^{34}$. In a Delphi Group, the most important is the balance of participation, rather than size, represented by the myriad points of view, expertise and interests in the context ${ }^{25}$. Studies indicate that the number between 10 and 18 specialists is the most adequate to develop the Method ${ }^{33-35}$. Experience with this method suggests caution in inviting more members than expected in the scenario of individuals, as there may be withdrawals ${ }^{33,34}$

The Delphi Matrix of Concordance (Chart 1) was submitted to the selected group of 13 specialists (judges), including: Regional Managers, Regional SN Coordinators and Technical Representatives of the SN-GCRC Conducting Group, and the Permanent Technical Chamber (CTP, acronym in Portuguese), and Municipal Managers; among them, three specialists work in the Nursing Academy - Arcoverde College of Nursing in Pernambuco (FENFA, acronym in Portuguese), chosen to seek greater representation of sectors of education that work in health due to their intellectual production, management capacity, and knowledge of practices related to Maternal and Child Health.

In this second Delphi moment, the specialists received, in an individual message sent by e-mail or in person, a Free and Informed Consent Term (TCLE, acronym in Portuguese), with explanatory text that presents the objectives of the Study and the way of construction of LM for Consensus by the Adjusted Delphi Method $^{32-35}$, containing the questionnaire with the Delphi Matrix of Concordance with the Objective Image Proposal (Instrument of validation of the categorization of the evaluation tools, based on the objectives of the $\mathrm{SN}$, inserted in the LM), with dimensions and fundamentals to assign grades from 0 to 10 . Zero corresponds to the non-importance and should be excluded, and ten represents the utmost importance. A space was intended for inclusion of possible new fundamentals.

After receiving the answers, the Means (M) and the Standard Deviations (SD) of the score were calculated to assess the importance attributed to the fundamentals, in order to verify the Consensus Degree of the Matrix among the opinions of the selected experts ${ }^{35,36}$.

The fundamentals were analyzed according to the importance attributed, using the following classification of the Mean points obtained ${ }^{36}$ : (a) $M<7=$ not very important; (b) $M \geq 7$ and $<9=$ important; and, (c) $M \geq 9=$ very important. Concerning the degree of consensus: (a) $S D \leq 1=$ consensus basis; (b) $S D>1$ and $<3$ = disagreement; and, (c) SD $\geq 3$ = great disagreement.

The following cut-off points were established for the fundamentals ${ }^{35}$ : (a) With a mean of lower than 7, it would not be part of the objective image for the $\mathrm{SN}$ evaluation at the macro-regional level; (b) with an SD lower than 3, it would be considered consensual and if it was classified as important, it should be included in the objective image; and, (c) with a mean equal to or greater than 7, and SD greater than or equal to 3, although important, it should not be included in the Objective Image because it would not be consensual.

After the Delphi Consensus Conference, which took place in public space at the headquarters of the VI Geres, the $3^{\text {(rd) }}$ Delphi moment began, where the specialists received in an individual message, in person, another Free and Informed Consent Form (TCLE, acronym in Portuguese), with an explanatory text that presented the objectives of the Study, with the construction of the Delphi Matrix of Concordance, with the proposed objective Image that is used as an evaluation tool ${ }^{24,28}$ of the Degree of Implementation (GI) of the SN program, assigning grades from 0 to 10 , on the Evaluation Matrix ${ }^{37}$. Zero would correspond to non-total implementation, and ten would indicate the maximum implementation of the fundamentals. A space was provided for comments in case the grade was zero. The Means (M) were calculated to evaluate the Gl of the dimensions and the presented fundamentals.

The judgment was made according to the assigned value, and the division by strata was used to guide the synthesis and the emission of evaluation. There was no need to attribute weights to the Fundamentals because, according to the level of agreement, all were considered very important. The observation of the $\mathrm{Gl}$ of $\mathrm{SN}$ was obtained through the Arithmetic Average from the Sum of the value assigned by each specialist, at the evaluation level for each Dimension and Fundamental, respectively; and division by the number of participants in this Stage. The adjusted and adopted judgment model followed to classify the GI, by size and foundation, was stratified into four levels by positive points: Between 9.00 and 10.0 points - Excellent (Implanted); between 7.00 and 8.99 points - Satisfactory; between 5.00 and 6.99 points - Unsatisfactory; and, finally, below 5.00 points - considered as critical.

This Research is part of a FACEPE Project No. 19/2015 and was approved by the Research Ethics Committee of the Aggeu Magalhães Institute (IAM, acronym in Portuguese) - Fiocruz-PE on 06/14/2016, under CAEE No. 50906915.0.0000.5190/2016 CONEP, according to Resolution No. 466, of December 12, 2012, of the National Health Council.

\section{RESULTS}

The recommended configuration of the objective image evaluation and the degree of implantation (GI) of the SN made it possible to improve the structuring and perception of the components to evaluate the fundamentals involved and the possible links between them from the elaboration of LM, as it guided the proposal composition of the Delphi Matrix of Consensus for the $\mathrm{SN}$ sent to the experts (judges) who issued two judgments, 
the level of agreement with the dimensions that composed the objective Image elaborated by the authors and the Gl of its fundamentals, according to these dimensions. They conceptualized the correlation of the fundamental with the dimension to which it is associated. However, there was no inclusion or exclusion of fundamentals; therefore, it did not present the need for remodeling, but it provided a measure of the increase of consensus, as well as the possible reduction of disagreement.

The SN Gl Assessment was set up by the score given by the 13 experts (judges) for each fundamental of the Consensus Matrix, and, after scoring, all 20 Selected Fundamentals of the six Dimensions were validated on the Level of Agreement as Very Important. Only the Fundamental (a6) obtained SD > 1, but, as its mean was 9.46 , its level of agreement was classified as Very Important, was considered consensual, and was included in the Goal Image.

The results are presented in (Table 1), with Dimensions and Fundamentals suggested in the Delphi Matrix, with the Mean, the respective Standard Deviation and Concordance Level.
When analyzing the $\mathrm{Gl}$ of the $\mathrm{SN}$ of the six Dimensions (directed by the final objectives of the LM), one observes that: one (d) was presented with a satisfactory level; four (a, b, c, e) showed Unsatisfactory Level; and another (f) was in Critical Level. Of the twenty Fundamentals listed: four obtained Satisfactory Level (a3, a5, d1, d2); fourteen had Unsatisfactory Levels (a1, a2, a4, a6, a7, b1, b2, b3, c1, c2, c3, e1, e2, f1); and, two presented Critical Level $(\mathrm{b} 4, \mathrm{f} 2)$.

The evaluation of the Gl of the SN program in the Macroeconomic Health III of PE was obtained by the Sum of the Averages of the Fundamentals of Dimensions, divided by the number of them, whose calculation resulted in a mean of 6.09. It was concluded that $\mathrm{SN}$ is classified as Unsatisfactory Level, corroborating the consensus judgment of the selected experts.

\section{DISCUSSION}

The objective-based method for evaluating the Stork Network at the Macro Regional level applied at the Consensus

Table 1. Evaluation of the proposed Objective Image and Degree of Implementation of the Stork Network at the Macro Regional Level; Semiarid Region, PE, Brazil, 2018.

Evaluation of Objective Image Proposal and Degree of Deployment of the Stork Network at the Macro Regional Level Region of the semi-arid, PE, Brazil, 2018

\begin{tabular}{|c|c|c|c|c|c|}
\hline \multirow[b]{2}{*}{ Dimension (Final Objectives) and Bases } & \multicolumn{5}{|c|}{ Delphi Stage Adjusted } \\
\hline & M & DP & $\begin{array}{c}\text { Level } \\
\text { Agreement }\end{array}$ & $\begin{array}{l}M \\
\text { GI }\end{array}$ & $\begin{array}{c}\text { Degree } \\
\text { Implemetaton }\end{array}$ \\
\hline (a) Macro regional Policy and Legislation & - & - & Very Important & 6.77 & Unsatisfatory \\
\hline a 1 & 10.0 & 0.0 & Very Important & 6.85 & unsatisfactory \\
\hline a 2 & 9.62 & 0.8 & Very Important & 5.69 & unsatisfactory \\
\hline a 3 & 9.85 & 0.4 & Very Important & 8.46 & Satisfactory \\
\hline a 4 & 9.70 & 0.6 & Very Important & 6.54 & unsatisfactory \\
\hline a 5 & 9.70 & 0.8 & Very Important & 7.38 & Satisfactory \\
\hline a 6 & 9.46 & 1.1 & Very Important & 6.92 & unsatisfactory \\
\hline a 7 & 9.38 & 0.8 & Very Important & 5.54 & unsatisfactory \\
\hline (b) Investiment in Actions & 9.93 & - & Very Important & 5.48 & Unsatisfatory \\
\hline b 1 & 9.92 & 0.3 & Very Important & 5.23 & unsatisfactory \\
\hline b 2 & 9.85 & 0.4 & Very Important & 6.31 & unsatisfactory \\
\hline b 3 & 9.62 & 0.7 & Very Important & 5.46 & unsatisfactory \\
\hline b 4 & 9.62 & 0.9 & Very Important & 4.92 & Critical \\
\hline $\begin{array}{l}\text { (c) Implementation of specific actions in Maternal and } \\
\text { Child Health Care }\end{array}$ & - & - & Very Important & 6.15 & Unsatisfatory \\
\hline c 1 & 9.54 & 0.7 & Very Important & 6.85 & Unsatisfactory \\
\hline c 2 & 9.77 & 0.6 & Very Important & 6.15 & Unsatisfactory \\
\hline c 3 & 9.62 & 0.9 & Very Important & 5.46 & Unsatisfactory \\
\hline $\begin{array}{l}\text { (d) Contracting and Capturing of Human Resources } \\
\text { (HR) }\end{array}$ & - & - & Very Important & 7.23 & Satisfactory \\
\hline d 1 & 9.70 & 0.6 & Very Important & 7.08 & Satisfactory \\
\hline
\end{tabular}


Evaluation of Objective Image Proposal and Degree of Deployment of the Stork Network at the Macro Regional Level Region of the semi-arid, PE, Brazil, 2018

\begin{tabular}{|c|c|c|c|c|c|}
\hline \multirow[b]{2}{*}{ Dimension (Final Objectives) and Bases } & \multicolumn{5}{|c|}{ Delphi Stage Adjusted } \\
\hline & M & DP & $\begin{array}{c}\text { Level } \\
\text { Agreement }\end{array}$ & $\begin{array}{l}\mathbf{M} \\
\mathbf{G I}\end{array}$ & $\begin{array}{c}\text { Degree } \\
\text { Implemetaton }\end{array}$ \\
\hline d 2 & 9.54 & 0.7 & Very Important & 7.38 & Satisfactory \\
\hline $\begin{array}{l}\text { (e) Stimulation of Acessibibility and participation of } \\
\text { the population in the defenseof their rights through } \\
\text { communication actions }\end{array}$ & - & - & Very Important & 5.65 & Unsatisfatory \\
\hline e 1 & 9.92 & 0.3 & Very Important & 5.15 & Unsatisfactory \\
\hline e 2 & 9.46 & 0.7 & Very Important & 6.15 & Unsatisfactory \\
\hline (f) Organization of services & - & - & Very Important & 4.11 & Critical \\
\hline f 1 & 9.54 & 0.9 & Very Important & 5.46 & Unsatisfactory \\
\hline f 2 & 9.77 & 0.4 & Very Important & 2.77 & Critical \\
\hline Degree of Total Deployment by Storm Network Fund & $n$ at Lev & II Ma & regional & 6.09 & Unsatisfatory \\
\hline
\end{tabular}

Source: Authors.

Conference with experts (judges) through the Adjusted Delphi Method $^{35,37}$ fills a knowledge gap from this perspective of peer judgment for $\mathrm{SN}$ evaluation. The instruments used proved to be appropriate to the complex situation, when unstructured problems related to intergovernmental network service programs can be better evaluated by specialists. The Adjusted Delphi Method transposed normative evaluation obstacles based only on the use of the traditional Logic Model.

The concept of the Degree of Deployment refers to the proper operationalization of an intervention ${ }^{15}$. In this sense, the $\mathrm{SN}$ in the III Macro-region of Health in Pernambuco was evaluated by pairs and presented unsatisfactory $\mathrm{Gl}$ in the view of selected specialists. The evaluation model used has advantages when applied in this type of study, when the structured opinion of specialists is potentially one of the best ways of evaluating complex situations that involves multiple levels of decision making and execution of actions in network of intergovernmental services. The LM-related Dimensions and Fundamentals related to the possible reduction of IM and MM were verified .

The experts' evaluation shows that the political articulation of the service network is a very fragile point in the process of implementation of $\mathrm{SN}$ at the Macro Regional level, when related to the parameters analyzed. Although there is a legal instrument to enhance the effectiveness of negotiations in the $\mathrm{CIR}^{16}$ for the implementation of $\mathrm{SN}^{2}$, it is necessary to increase the articulation capacity of the network, since there is no regional policy that prioritizes these issues in the CIR where there is a lack of negotiations for the driving SN.

Even with the current attributions delegated to committees and the regional mobilization around SN13, the strategic information available is not used in its planning and structuring process and there are no discussions aimed at formalizing inter-financial agreements between municipalities to reach the objectives to strengthen integrality in the context of SN.
The initiatives developed to strengthen the Stork Network program in the Third Macro Region and to aggregate the strategic institutions were irrelevant. Among the articulations ${ }^{16,17}$, it can be observed the ones carried out in an incipient way between the state and municipal administrations (Regional Health Offices and Municipal Health Secretariats), in order to implant and implement the network in an articulated way.

Evidences in this sense can be observed with the application of the Consensus Matrix. No new investment in actions9 related to the implantation of a resolution network in the macro-region for $\mathrm{SN}$ is identified, since there was no expansion of high-risk beds and no creation of high-risk reference maternity. Similarly, no regulation centers for obstetric and neonatal beds, ambulatory and emergency regulation, consultations and examinations. Due to the lack of monitoring of the actions to correct the problems related to the program, there are no loco-regional alternatives to improve investments, which would allow the expansion of SN's actions different from what has been observed in relation to their reduction.

Specific actions in maternal and child health care are unsatisfactory, confirming that, in order for $\mathrm{SN}$ to be able to respond fully to the framework observed in this area, it should cover the problem of the implementation of integrality as a structuring principle $^{12,13}$, given the shortcomings of offer of mentioned services. There are coordination services to Maternal and Child Health, but they are only partially integrated and there is no compliance of the SN with what was proposed by Ordinance $1.459 / 11$, which needs to be redesigned based on the strengthening of primary care for care management.

As for the issue of Human Resources Recruitment and Procurement in the Macro Regional III being in a satisfactory condition, given the fact that there was a public tender recently, there is still a shortage of obstetricians. It has a technical team (doctors, nurses, and nursing technicians) that meets the needs of basic 
care, but not specifically for the SN Program. In this circumstance, it is salutary to emphasize the importance of the nursing team in the configuration of the Maternal and Child Health Care Network ${ }^{38}$, because, in order to implement this model, it plays an important role in endorsing the principles of humanization, good practices and labor and birth security ${ }^{39}$. Currently, there is a reorganization of this service ${ }^{13}$. Improvements are observed regarding the organization and qualification of professionals, and of services with information system and service to the public.

There is no encouragement to the participation of the population in defense of their rights on accessibility through communication actions, and there is an incipient communication between collegiate and population about the conduction of SN. What is endorsed, that is, the Gl's issue of the fundamentals in perspective, points to the increased vulnerability of women and children in this population ${ }^{3,10}$.

There is a disarticulation in the organization of services ${ }^{9,11}$; and a fragmentation of actions ${ }^{12}$ that present a critical situation. For there is no guarantee of bed and bonding of the pregnant woman, transportation voucher, and taxi voucher to the place of birth in the maternity hospitals or public reference hospitals. This reflects in the indicators of morbidity and mortality that, in a curious way, have deteriorated punctually due to complications arising from pregnancy, childbirth, puerperium, and child care, where the Northeast Region historically always has a higher concentration of rates ${ }^{1,3}$. This can be confirmed, because the Macro Regional III, which has a large territorial area in the semi-arid, bordering four States of the Federation (Ceará, Paraiba, Alagoas, and Bahia), is located far from the state capital (Recife); and there is no Stork SAMU offering (equipped) to the newborn who needs outpatient emergency, showing a critical condition, explicitly demonstrating a vulnerability ${ }^{3,4}$, in this basic component of $\mathrm{SN}$.

\section{FINAL CONSIDERATIONS}

This work evaluates, through specialists, the implementation of the SN Program, and points to an unsatisfactory condition of its implantation in the III Macro-Regional Health. This approach, with application of the Adjusted Delphi Method, was shown to be coherent with the complexity of the object, in the face of specific models for this purpose based on institutional relations in the regionalization of SUS.

It is imperative to highlight the worrying situation of $\mathrm{SN}$ in the Macro-Regional Health Center, especially in this context, the essential role of the nursing team for Maternal and Child Health Care, as well as significant social support, in the face of a vulnerable population and in the semi-arid region of Pernambuco in a politically and economically adverse scenario. There is a possibility that these failures are part of an even broader picture in the country, due to its intergovernmental nature in view of the unfavorable contextual issues that characterize the current problems of public health in Brazil, after an institutional crisis and a profound change of policies, from of the federal government, with austerity measures adopted in the SUS with Constitutional Amendment No. 95/2016.
As this situation is inevitably contingent, it indicates the need for further evaluations of government programs implemented in a shared regional network. In this adverse context since 2017, it is essential to implement and strengthen $\mathrm{SN}$ in Pernambuco. It was concluded that, according to the circumstances, the finalistic objectives pursued by the program are not being fully achieved, due to the unsatisfactory level of implementation presented by the Delphi Matrix, which can consistently validate the SN GI, from the perspective of a regional network.

\section{FINANCIAL SUPPORT}

Research Project with the title "Integrated and Sustainable Assistance Networks: theory, practice and innovation possibilities in the interinstitutional dynamics of SUS regulation (REG-SUS)" financed by FACEPE/PROEP - No. 19/2015.

\section{REFERENCES}

1. Ceron MI, Barbieri A, Fonsêca LM, Fedosse E. Assistência pré-natal na percepção de puérperas provenientes de diferentes serviços de saúde. Rev CEFAC [Internet]. 2013 May/Jun; [cited 2018 Dec 1]; 15(3):653-62. Available from: http://www.scielo.br/pdf/rcefac/v15n3/184-11.pdf. DOI: 10.1590/S1516-18462012005000081

2. Portaria № 1.459 , de 24 de junho de 2011 . Institui, no âmbito do Sistema Único de Saúde - SUS - a Rede Cegonha. Brasília (DF): Diário Oficial da União; 2011. [cited 2018 Jan 28]. Available from: http://bvsms.saude. gov.br/bvs/saudelegis/gm/2011/prt1459_24_06_2011.html.

3. Oliveira SKM, Pereira MM, Freitas DA, Caldeira AP. Saúde maternoinfantil em comunidades quilombolas no norte de Minas Gerais. Cad Saúde Coletiva [Internet]. 2014; (3):307-13. Available from: http://www. scielo.br/pdf/cadsc/v22n3/1414-462X-cadsc-22-03-0307.pdf. DOI: 10.1590/1414-462X201400030013

4. Martinelli KG, Santos Neto ET, Gama SGN, Oliveira AE. Adequação do processo da assistência pré-natal segundo os critérios do Programa de Humanização Pré-natal e Nascimento e Rede Cegonha. Rev Bras Ginecol Obstet [Internet]. 2014; [cited 2018 Dec 20]; 36(2):5664. Available from: http://www.scielo.br/pdf/rbgo/v36n2/0100-7203rbgo-36-02-00056.pdf. DOI: 10.1590/S0100-72032014000200003

5. Nascimento SG, Oliveira CM, Sposito V, Ferreira DKS, Bonfim CV. Mortalidade Infantil por causas evitáveis em uma cidade do Nordeste do Brasil. Rev Bras Enferm [Internet]. 2014 Mar/Apr; [cited 2018 Dec 20]; 67(2):208-12. Available from: http://www.scielo.br/pdf/reben/v67n2/00347167-reben-67-02-0208.pdf. DOI: 10.5935/0034-7167.20140027

6. Associação Brasileira de Saúde Coletiva (ABRASCO). Especial Abrasco sobre o aumento da mortalidade infantil e materna no Brasil. [cited 2018 Sep 2]. Available from: https://www.abrasco.org.br/site/outras-noticias/ institucional/especial-abrasco-sobre-o-aumento-da-mortalidade-infantile-materna-no-brasil/36777/

7. Organização das Nações Unidas (ONU). ONU BR Nações Unidas no Brasil. Agência da ONU discute Prevenção à Mortalidade Materna em Congresso no Rio. [cited 2018 Sep 1]. Available from: https:// nacoesunidas.org/agencia-da-onu-discute-prevencao-a-mortalidadematerna-em-congresso-no-rio/

8. Organização das Nações Unidas (ONU). ONU BR Nações Unidas no Brasil. UNICEF: 386 mil bebes nasceram no dia $1^{\circ}$ dia de 2018. [cited 2018 Sep 1]. Available from: https://nacoesunidas.org/unicef-386-milbebes-nasceram-10-dia-2018/

9. Ministério da Saúde (BR). Secretaria de Vigilância em Saúde. Departamento de Análise de Situação de Saúde. Saúde Brasil, 2009 uma análise da situação de saúde e da agenda nacional e internacional de prioridades em saúde. Brasília (DF): Ministério da Saúde; 2010. [cited 2018 Apr 21]. Available from: http://bvsms.saude.gov.br/bvs/ publicacoes/saude_brasil_2009.pdf 
10. Rasella D, Basu S, Hone T, Paes-Sousa R, Ocké-Reis CO, Millett C. Child morbidity and mortality associated with alternative policy responses to the economic crisis in Brazil: A nationwide microsimulation study. PLoS Med [Internet]. 2018 May; [cited 2018 May 27]; 15(5):e1002570. Available from: https://www.ncbi.nlm.nih.gov/pubmed/?term=PLoS+Med.+2018+May\%3 B+15(5)\%3A+e1002570. DOI: 10.1371/journal.pmed.1002570

11. Biscarde DGS, Pinto KA, Oliveira MTS, Barbosa JC, Oliveira BV, Sousa JS. Rede de atenção à saúde materno-infantil: desafios para a organização de serviços de saúde no município de Salvador-Bahia. $2^{\circ}$ Congresso Brasileiro de Política, Planejamento e Gestão em Saúde. Belo Horizonte: Universidade Federal da Bahia - Escola de Enfermagem; 2013. [cited 2018 May 12]. Available from: http://www.politicaemsaude.com.br/anais/ trabalhos/publicacoes/242.pdf

12. Arruda C, Lopes SGR, Koerich MHAL, Winck DR, Meirelles BHS, Mello ALSF. Redes de atenção à saúde sob a luz da teoria da complexidade. Esc Anna Nery [Internet]. 2015; [cited 2018 Aug 18]; 19(1):169-73. Available from: http://eean.edu.br/detalhe_artigo.asp?id=1263. DOI: $10.5935 / 1414-$ 8145.20150023

13. Santos AM. Gestão do cuidado na microrregião de saúde de Vitória da Conquista - BA: desafios para constituição de rede regionalizada com cuidados coordenados pela Atenção Primária à Saúde [tese]. Rio de Janeiro: Escola Nacional de Saúde Pública Sérgio Arouca. Fundação Oswaldo Cruz; 2013.

14. Ministério da Saúde (BR). Secretaria de Atenção à Saúde. Manual prático para implementação da Rede Cegonha. Brasília (DF): Ministério da Saúde; 2011.

15. Cavalcanti PCS, Gurgel Júnior GD, Vasconcelos ALR, Guerrero AVP. Um Modelo Lógico da Rede Cegonha. Physis [Internet]. 2013;23(4):1297316. Available from: http://www.scielo.br/scielo.php?pid=S010373312013000400014\&script=sci_abstract\&tlng=pt. DOI: 10.1590/S010373312013000400014

16. Redes de Atenção à Saúde: $A$ atenção à Saúde Organizada em Redes. São Luís: Universidade Federal do Maranhão; 2016. [cited 2018 Dec 20]. Available from: http://www.unasus.ufma.br/site/files/livros_isbn/ isbn_redes01.pdf

17. Leal MC. Parto e nascimento no Brasil: um cenário em processo de mudança. Cad Saúde Pública [Internet]. 2018; [cited 2018 Aug 28]; 34(5):e00063818. Available from: http://www.scielo.br/pdf/csp/v34n5/16784464-csp-34-05-e00063818.pdf. DOI: 10.1590/0102-311X00063818

18. Tomasi E, Fernandes PAA, Fischer T, Siqueira FCV, Silveira DS, Thumé E, et al. Qualidade da atenção pré-natal na rede básica de saúde no Brasil: indicadores e desigualdades sociais. Cad Saúde Pública [Internet].2017; [cited 2018 Aug 20];33(3):e00195815. Available from: http://www.scielo.br/ pdf/csp/v33n3/1678-4464-csp-33-03-e00195815.pdf.DOI: 10.1590/0102$311 \times 00195815$

19. Bezerra LCA, Cazarin G, Alves CKA. Modelagem de programas: da teoria à operacionalização. In: Samico I, Felisberto E, Figueiró AC, Frias PG, orgs. Avaliação em saúde: bases conceituais e operacionais. Rio de Janeiro: MedBook; 2010. p. 65-78.

20. Hartz ZMA, Silva LMV. Avaliação em saúde: dos modelos teóricos à prática na avaliação de programas e sistemas de saúde. Salvador: EDUFBA; 2005.

21. Hartz ZMA. Avaliação dos programas de saúde: perspectivas teóricometodológicas e políticas institucionais. Ciênc Saúde Coletiva [Internet]. 1999; [cited 2018 Sep 21]; 4(2):341-53. Available from: http://www. scielo.br/scielo.php?pid=S1413-81231999000200009\&script=sci_ abstract\&tIng=pt. DOI: 10.1590/S141381231999000200009

22. Oliveira SRA, Teixeira CF. Avaliação da regionalização do SUS: construção de Modelo Teórico-lógico. Rev Baiana Saúde Pública [Internet]. 2013;37(1):236-54. Available from: http://rbsp.sesab.ba.gov.br/index.php/ rbsp/article/view/162. DOI: 10.22278/23182660.2013.v37.n1.a162

23. Flick U. Triangulation in Qualitative Research. In: Flick U, von Kardoff E, Steinke I, orgs. A Companion to Qualitative Research. London: SAGE; 2004.

24. Januzzi PM. Avaliação de programas sociais no Bra sil: repensando práticas e metodologias das pesqui sas avaliativas. Planej Polít Públicas [Internet]. 2011; [cited 2018 Jul 1]; 36:251-75. Available from: http://www. ipea.gov.br/ppp/index.php/PPP/article/view/228/212
25. Bloor M, Sampson H, Baker S, Dahlgren K. Useful but no Oracle: Reflections on the use of a Delphi Group in a multi-methods policy research study. Qual Res [Internet]. 2015;15(1):57-70. Available from: https://journals.sagepub.com/doi/pdf/10.1177/1468794113504103. DOI: $10.1177 / 1468794113504103$

26. Gurgel Júnior GD. Health Sector Reform in Brazil: Past, present and future ATheoretical Approach to Structural Changes[Thesis].Manchester: Faculty of Humanities, School of Social Sciences, University of Manchester;2008.

27. Pereira RDM, Alvim NAT. Técnica Delphi no diálogo com enfermeiros sobre a acupuntura como proposta de intervenção em enfermagem. Esc Anna Nery [Internet]. 2015; [cited 2018 Aug 10]; 19(1):174-80. Available from: http://eean.edu.br/detalhe_artigo.asp?id=1262. DOI: $10.5935 / 1414$ 8145.20150024

28. Champagne F, Contandriopoulos AP, Brousselle A, Hartz Z, Denis JL. Avaliação no Campo da Saúde: conceitos e métodos. In: Brousselle A, org Avaliação: conceitos e métodos. Rio de Janeiro:Editora Fiocruz; 2011.41 p.

29. Governo do Estado de Pernambuco. Secretaria Estadual de Saúde. [cited 2018 Sep 4]. Available from: http://portal.saude.pe.gov.br/secretariaexecutiva-de-coordenacao-geral/gerencias-regionais-de-saude

30. Ferraro AHA, Costa EA, Vieira-da-Silva LM. Imagem-objetivo para descentralização da vigilância sanitária em nível municipal. Cad Saúde Pública [Internet]. 2009 Oct; [cited 2018 Feb 5]; 25(10):2201-17. Available from: https://repositorio.ufba.br/ri/bitstream/ri/2056/1/per\%20 nac2009.8.pdf. DOI: 10.1590/S0102-311X2009001000011

31. Lopes GVDO, Vilasbôas ALQ, Castellanos MEP. Atenção Domiciliar na Estratégia Saúde da Família: avaliação do grau de implantação em Camaçari (BA). Saúde Debate [Internet]. 2017;41(no.spe3):24154. Available from: http://www.scielo.br/scielo.php?script=sci abstract\&pid=S0103-11042017000700241\&lng=pt\&nrm=iso. DOI: 10.1590/0103-11042017s318

32. Fonsêca GS, Junqueira SR. Programa de Educação pelo Trabalho para a Saúde da Universidade de São Paulo (Campus Capital): o olhar dos tutores. Ciênc Saúde Co letiva [Internet].2014;19(4):1151-62. Available from: http:// www.scielo.br/scielo.php?pid=S1413-81232014000401151\&script=sci abstract\&tlng=pt. DOI: 10.1590/1413-81232014194.00192013.

33. Boulkedid R, Abdoul H, Loustau M, Sibony O, Alberti C. Using and reporting the Delphi method for selec ting healthcare quality indicators: a systematic re view.PLoS One [Internet].2011;6(6):e20476. Available from: https://www. ncbi.nlm.nih.gov/pubmed/21694759.DOI:10.1371/journal.pone.0020476.

34. Valdés MG, Marín MS. Empleo del método Delphi en investigaciones sobre salud publicadas en revistas cien tíficas cubanas. Rev Cub Inf Cienc Salud [Internet]. 2013 Apr/Jun; [cited 2018 May 2]; 24(2):133-44. Available from: http://scielo.sld.cu/scielo.php?script=sci_arttext\&pid $=$ S2307-21132013000200004

35. Pessoa TRRF, Noro LRA. Caminhos para a avaliação da formação em Odontologia: construção de modelo lógico e validação de critérios. Ciênc Saúde Coletiva [Internet]. 2015;20(7):2277-90. Available from: http:// www.scielo.br/scielo.php?pid=S1413-81232015000702277\&script=sci abstract\&tlng=pt. DOI: $10.1590 / 1413-81232015207.13182014$

36. Souza LEPF, Vieira-da-Silva LM, Hartz ZM. A Conferência de consenso sobre a imagem-objetivo da descentralização da atenção à saúde no Brasil. In: Hartz ZMA, Vieira-da-Silva LM, orgs. Avaliação em saúde: dos modelos teóricos à prática na avaliação de programas e sistemas de saúde. Salvador: EDUFBA/RJ: Fiocruz; 2005. p. 65-102.

37. Alves CKA, Natal S, Felisberto E, Samico I. Interpretação e Análise das Informações: O Uso de Matrizes, Critérios, Indicadores e Padrões. In Samico I, Felisberto E, Figueiró AC, Frias PG, org. Avaliação em Saúde: Bases Conceituais e Operacionais. Rio de Janeiro: MedBook; 2010.98 p.

38. Gomes, IM, Lacerda, MR, Rodrigues, JAP, Camargo, TB, Zatoni, DCP, Nascimento, VS . O apoio da rede social no cuidado domiciliar. Esc Anna Nery [Internet]. 2016; [cited 2018 Oct 26];20(3):e20160062. Available from http://www.scielo.br/pdf/ean/v20n3/1414-8145-ean-20-03-20160062.pdf. DOI: $10.5935 / 1414-8145.20160062$

39. Oliveira FAM, Leal GC, Wolff LDG, Rabelo M, Poliquesi CB. Reflexões acerca da atuação do enfermeiro na Rede Cegonha. Rev Enferm UFPE On Line (Recife) [Internet]. 2016 Feb; [cited 2018 Dec 22]; 10(Supl 2):867-74. Available from: file:///C:/Users/susana/Downloads/1103024267-1-PB\%20(1).pdf. DOI: 10.5205/reuol.6884-59404-2 